\title{
Explaining the Maximal Intensity Exercise Performance of Young People 探索兒童最大強度運動能力
}

\author{
Michael CHIA \\ Physical Education and Sports Science, National Institute of Education \\ Nanyang Technological University, SINGAPORE \\ 謝永和 \\ 新加坡南洋理工大學國立敎育學院 \\ 體育與運動科學組
}

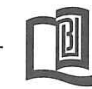

\begin{abstract}
Explanations for children maximal intensity exercise fitness in the literature fluctuate between the incapacity of young children to generate energy anaerobically and a reduced need for the metabolic pathway. A number of propositions are advanced to explain young children's relative inaptitude in anaerobic performance in comparison with older children and adults. These range from a smaller quantity of active muscle mass to perform the anaerobic task, to the quality of the muscle which may not yet be energetically, chemically or neurogenically mature, in comparison to their older and more mature counterparts. No one single factor, whether quantitative or qualitative in nature, however, can account exclusively for the anaerobic fitness of young people. The other persuasive argument advanced is that children are less reliant than adults on the anaerobic energy pathway, for their energy supply. Arguments supporting such a contention include a swifter oxygen uptake response in children during high intensity exercise, a greater blood flow to muscle and greater oxygen extraction capability, and a blunted response to catecholamines during high intensity exercise. Either way, the evidence in the current literature is equivocal. Future research employing the use of non-invasive methods such as MRI to determine muscle fibre type, MRS to determine baseline energy substrates and utilisation rates during exercise, as well as mass spectroscopy to analyse oxygen uptake kinetics and other ventilatory responses during high intensity exercise, may help bring to the fore new knowledge to a most interesting area of research in children's exercise.
\end{abstract}

\section{摘 要}

有關兒童最大強度運動能力的文獻報導結果不一。有些學者認為兒童的無氧代謝的能力非常低下, 而有些學者則認為是因為兒 童對無氧代謝的需求較低。一些文獻闡述了年幼兒童無氧代謝能力較少年或成人低下的原因是由於肌肉的數量, 尤其是無氧代謝能 力較強的肌肉數量較少以及肌肉在能量代謝、生物化學和神經支配方面的成熟度較成年人低。而僅以某一單一因素, 無論是肌肉數 量還是成熟度, 都不足以解釋兒童無氧代謝能力的特點。另一些研究則表明兒童對無氧供能的需求量較成年人低, 主要表現在兒童 進行大強度運動時其攝氧量急劇上升, 肌肉的血流量和氧攝取量明顯增加, 以及運動中對兒茶酚胺的反應不敏感等。然而, 迄今為 止對於兒童最大強度運動能力的特點仍不十分清楚, 需作進一步的研究。應用無創傷性方法, 如應用核磁共振成像法檢測肌纖維類 型、核磁共振光譜分析法測定運動中的能量物質及其利用率, 以及質譜法分析大強度運動過程中攝氧量的動態變化和通氣量的變化 等, 則將有助於提高和促進兒童體育科學研究。

\section{Introduction}

Explanations for children's maximal intensity exercise performance in the literature fluctuate between the incapacity of young children to release anaerobic energy because of an immature anaerobic metabolic pathway, and a reduced need for the metabolic pathway. This review attempts to put into perspective the on-going debate on the matter. A number of 
explanations have been proposed to account for the observed anaerobic fitness of children. Some of these include: a lower muscle mass (Bar-Or, 1989); a lower lactate accumulation during exercise (Macek, 1986); lower levels of testosterone (Krotkiewski et al, 1980; Falk \& Bar-Or, 1993); lower resting levels of intramuscular glycogen and creatine phosphate (Inbar \& Bar-Or, 1983, 1986; Eriksson, 1980); lower activity levels of phosphofructokinase and other glycolytic enzymes (Fournier et al, 1982; Bar-Or, 1983; Eriksson et al, 1973), a lower rate of anaerobic utilisation of glycogen (Bar-Or, 1983), a lower sympathetic activity (Lehmann et al, 1981)- which is hypothesised to increase lactate removal because of increased blood flow to the liver ( Brooks, 1985; Zwiren, 1989); a shorter half-time increase in oxygen uptake prior to reaching steady state (Bar-Or, 1983); neuromuscular factors (Sargeant, 1989); and the architectural structure of the child muscle (Davies, 1985). It appears that an interaction of the reasons put forward best explains children's observed anaerobic performance.

\section{Muscle Mass as a Factor Affecting the Maximal Intensity Exercise of Young People}

In prepubertal children, muscle accounts for $25-35 \%$ of their body mass, which after puberty, rises to $40-45 \%$ in boys and $35-38 \%$ in girls (Vrijens, 1978; Wells, 1989), owing to the differential effects of androgens during puberty. Lloyd and May (1987), reported that between childhood and puberty, the increase in muscle mass is greater than the increase in total body mass and total body fat. Under normal circumstances, muscle strength (which is a key component of power) is highly dependent on gross muscle size. Based on urinary creatine excretion rates, and data provided by Blimkie et al (1989), muscle mass increases about five-fold in males from $7.5 \mathrm{~kg}$ to $37 \mathrm{~kg}$ (42-53.6\% of body mass), and about three-fold in females, from $6.9 \mathrm{~kg}$ to $24 \mathrm{~kg}$ (40.2-42.5\% of body mass), for the age-span 5 to 17.5 years.

Additionally, beyond age seven years, males have a larger absolute and relative (kg muscle per $\mathrm{kg}$ body mass) amount of muscle relative to females (Malina, 1969). This is in agreement with the finding that boys have a greater percentage of lean body mass than girls, even in the pre-pubertal years (Rowland, 1990). Nevertheless, the rate of increase in muscle mass and the percentage change with growth will vary from muscle to muscle. The effect of this differential pattern of muscle mass increase on anaerobic power for specific muscle groups has apparently not been adequately researched. Early data suggest that leg musculature constitutes an increasing percentage of total body mass with age, from $40 \%$ at birth to $55 \%$ at maturity
(Scammon, 1923; cited by Rowland, 1990). Leg length accounts for about $45 \%$ of the stature of an eight-year-old boy while in a 13-year-old boy, it accounts for 55\% (Lowery, 1973). These alterations in body proportions with growth in children add to age-related differences in exercising muscle mass relative to body mass in exercise involving the lower limbs (running and cycling). Indeed, lean limb volume explained a greater variance of the performance in the WAnT than total body mass in adolescents (Blimkie et al, 1989) and in young adults (Murphy et al, 1984). These observations are corroborated by other studies. For example, Mercier et al (1992), studied the peak anaerobic power outputs of 69 boys aged 11-19 years, in relation to lean body mass (LBM), leg volume (LV), and total muscle mass (TMM). The muscle and volume values were derived from calculations based on anthropometric techniques. They reported that peak anaerobic power output, derived from F-V tests, increases from 11 - 19 years, and is correlated with LV ( $\mathrm{r}=0.84)$ and TMM ( $\mathrm{r}=0.88)$, but is best correlated with LBM ( $\mathrm{r}=0.94)$, which contributed $88 \%$ of the total variance optimised peak anaerobic power output. Blimkie et al (1989) showed that peak anaerobic arm power in boys is highly associated with fat-free mass. Williams et al (1993), used magnetic resonance imaging scans (MRI) to study the relationships among anaerobic performances in the WAnT for legs, and peak V02 in a group of fifty, 11 year-old children (25 girls and 25 boys). They reported significant correlations between thigh muscle area and peak V02 in both boys and girls. However only the girls' performance in the WAnT is reported as significant with thigh muscle area even though no gender difference was apparent in the anaerobic performance.

Although anthropometric data provide a good estimate of limb musculature, Mercier et al (1992), caution that such calculations do not provide information about the proportion of the muscles that are activated during the exercise. Since muscle mass alone cannot explain all the variance in anaerobic fitness as determined in performance tests, it is also plausible that qualitative differences that are size-independent can account for some of the observed variance. Sargeant et al (1984), for instance, argue that structural factors in muscle can help explain child-adult differences in anaerobic performance. They explained that when longitudinal growth stops, adults continue to increase the cross-sectional area of their muscle fibres, thus changing the angle of pennation and effective force production. This gives adults a greater mechanical advantage, and therefore a greater force producing muscle, over growing children. Additionally, Backman and Henriksson (1988), who studied the skeletal muscle characteristics of children aged nine to 15 years, suggest that the elastic properties of muscle 
(and therefore force-generating potential) increase throughout pre-puberty to attain a maximum value only around age 15 years. Younger children therefore, do not yet posses the full force-generating capability, in comparison to adolescents and young adults. In essence, quantitative differences in muscle mass between young people and young adults, can explain for much but not all of the observed variance in their comparative fitness in anaerobic tasks. Other size-independent and qualitative reasons must be sought to account for the remaining variance.

\section{Muscle Fibre Distribution as a Factor Affecting Maximal Intensity Exercise of Young People}

A maturation of skeletal muscle fibre type pattern can also account for growth-related differences in the metabolic response to high intensity exercise but the literature evidence is equivocal. Reviews of adult skeletal muscle fibre development and fibre differentiation are available (Baldwin, 1984; Malina $\&$ Bouchard, 1986). In contrast, equivalent data on children are scant because of ethical restrictions imposed on the use of invasive techniques in obtaining muscle samples from children.

Nevertheless, a number of cross-sectional studies based on autopsies of previously healthy males are available (Lexell et al, 1992; Oertel, 1988). Lexell et al (1992) reported that proportions of Type II fibres from sections of the vastus lateralis muscle rose from ages five years to about 20 years $(35 \%$ vs. 50\%). Oertel (1988), examined 113 subjects between the ages one week and 20 years of post-mortem accident victims and reported that the proportion of Type I fibres increased from $40 \%$ at birth to about $60 \%$ by age two years. Thereafter, the relative proportions of Type I and Type II fibres remained constant. In support, Lundberg et al (1979) reported that 59\% of the fibres in the vastus lateralis were Type I in a group of 25 children aged between two months and 11 years. That compares favourably with the $60 \%$ figure described by Eriksson et al (1972) in 16 boys aged between 12 and 15 years.

In their muscle biopsy study, Bell et al (1980) demonstrated that in six year old children ( 7 girls and 5 boys), Type I fibres accounted for 59\% and Type II fibres accounted for $20 \%$ whilst the remaining $21 \%$ were intermediate fibre types (fast twitch oxidative). In support, du Plessis et al (1985), showed that adolescent boys have three times more transitional muscle fibres than adults ( $13 \%$ versus $4 \%$ ). It appears that the major change documented in the first year of life is the transformation of transitional fibre Type IIc into Type I fibres with the proportions of Types II a and II $b$ fibres remaining relatively constant. Such an observation is also documented for rodent muscles (gastrocnemius), barring the different timeframes when those transformations occur (Brooke et al, 1969).

Although limited, collectively, the cited studies are consistent in the finding that the proportion of Type I muscle fibres in the vastus lateralis of children is about $60 \%$. In comparison, the typical values of Type I fibres of the same muscle reported for sedentary adults are about 35-45\% (Eriksson, 1972). However, the $60 \%$ Type I figure for children is consistent with values reported for trained adult endurance athletes (52-61\%), even though much higher values of $90-98 \%$ have been documented in top world class runners (Costill et al, 1976). These results nurture the speculation that children are better equipped fibrewise for oxidative metabolism than glycolytic metabolism, which may explain in part, children's lower anaerobic performance.

Brooks (1985) suggested that increased lactate production at the lactate threshold (LT), is related to the increased recruitment of Type II fibres. As prepubescent children have less Type II fibres than adolescents and adults, it is conceivable that proportionately less glycolytic fibres are recruited at exercise intensities at or above the LT. This can account for a lower lactate level observed in children compared to adults for a similarly matched exercise demand at or above the LT.

Caution is advised when interpreting results of muscle biopsies, primarily because most biopsy data are from dated studies, which involve small sample sizes. Lexell et al, (1985), argue that estimations of fibre composition of, for instance, the vastus lateralis muscle, are based on a small number of fibres (normally less than 1000), from a muscle that contains well over 500000 fibres. In addition, significant variations in fibre composition may occur from biopsy to biopsy, superficial to deep, and proximal to distal (Elder et al, 1982; Lexell et al, 1985; Simoneau et al, 1985). The classification of fibres into discrete groups is a methodological convenience, since in many situations, fibres demonstrate a continuum of properties across types (Sargeant, 1994). Therefore it cannot be accepted without doubt that fibres identified on the basis of histochemistry as belonging to the same type will necessarily have totally identical properties. Recent developments have indicated that the classification of muscle fibre type based on their slow(Type I) or fast (Type II) twitch characteristics may be overly simplistic and does not consider the full extent of myosin heavy chain $(\mathrm{MyHC})$ isoform diversity of human muscle and its potential impact on energy turnover (Sant' Ana Pereira et al, 1996). Based on the new classification proposed by Ennion et al (1995), that in essence is based on the MyHC isoforms expressed, single muscle fibres can be characterised 
as Type I, Type IIA, Type IIX and Type IIAX. In adults, at least, it is clear that human skeletal muscles contain many hybrid fibres co-expressing variable amounts of distinct MyHC isoforms that lie on a continuum (Sant' Ana Pereira et al, 1996 ). The situation in young people awaits future investigations based on non-invasive techniques of studying muscle fibre types.

The availability of Magnetic Resonance Imaging (MRI) to estimate muscle fibre composition (Kuno et al, 1988; Houmard et al, 1995) offers a promising way forward, albeit an expensive one, as the technique is non-invasive and circumvents the need for ionising radiation. The procedure has been carried out on adults but studies on children have apparently not been done.

\section{Energy Substrate Levels as Factors Affecting Maximal Intensity Exercise of Young People}

The three main energy substrates for anaerobic metabolism are adenosine triphosphate (ATP), creatine phosphate (CP) and glycogen. There are apparently no longitudinal data on the energy substrate levels in children during growth and maturation. The invasiveness of the current technique (muscle biopsy) needed to study the intra-muscular characteristics, continues to render the approach inappropriate in the study of normal children.

Only a handful of cross-sectional studies on children, exclusively on boys, which focus on the metabolic properties of the muscle have been conducted and they show that muscle concentrations of ATP and CP at one year of age are about $60 \%$ of adult levels (Berg et al, 1986; Eriksson et al, 1974; Haralambie, 1982). But studies on 11-year old boys show that, although the levels of ATP, CP and enzymes necessary for anaerobic metabolism are similar to or only slightly lower than those of adults, their rates of utilisation, however, during exercise are less than those observed in adults (Bar-Or, 1983; Eriksson \& Saltin, 1974). Macek (1986), however, noted that the values are higher if the children are trained. But both Bar-Or, (1983) and Eriksson and Saltin, (1974), noted that pre-pubertal children have much less muscle glycogen than adults, the former attaining adult values only between 15 and 16 years of age. The metabolic properties of skeletal muscle in pre-pubertal boys are summarised in Table 1.
Table 1. Quantitative Differences in Child-adult Substrate Availability and Utilisation. Juxtaposed data of Eriksson $(1971,1974)$, Haralambie (1982) and Berg (1986).

\begin{tabular}{|c|c|c|c|}
\hline Substrate & $\begin{array}{c}\text { Muscle } \\
\text { concentration } \\
{\left[\mathrm{mM} . \mathrm{kg}^{-1} \text { wet muscle }\right]}\end{array}$ & $\begin{array}{l}\text { Compared } \\
\text { to adults }\end{array}$ & $\begin{array}{l}\text { Utilisation rate } \\
\text { compared to } \\
\text { adults }\end{array}$ \\
\hline ATP & $3-5$ & Same & Same \\
\hline $\mathrm{CP}$ & $12-22$ & Lower & Same or lower \\
\hline Glycogen & $50-60$ & Lower & Same or lower \\
\hline
\end{tabular}

There are suggestions that children are better equipped than adults to use fat as a fuel during exercise. This translates to a glycogen-sparring effect and a delayed onset of anaerobic metabolism during progressive exercise (Welsman \& Armstrong, 1995). Increased levels of blood glycerol, which indicate elevated intensity of lipolysis in the adipose tissue, are reported by Macek et al (1976) and is consistent with the results of Eriksson et al (1973) on boys. However, Carlson et al (1963), cited by Macek (1986), reported no apparent difference in glycerol levels of boys compared with adults. Evidence from magnetic resonance spectroscopy (MRS) studies supports the view that children are better equipped with faster muscle high energy phosphate kinetics (higher rate of oxidative phosphorylation) than adults, and as such, seem to rely less on anaerobic metabolism compared to adults, when matched for an anaerobic task (Zanconato et al, 1993). The authors studied the levels of inorganic phosphate (Pi), creatine phosphate $(\mathrm{CP})$ and hydrogen ions $(\mathrm{pH})$ of the calf muscles at rest and during exercise of 10 children ( 8 boys and 2 girls; mean age $9.3 \pm 1.0 \mathrm{y}$.) and 8 adults ( 5 men and 3 women, mean age $33.7 \pm 6.9 y$.$) , using$ magnetic resonance spectroscopy techniques. The study demonstrated that during high intensity exercise (repeated full right plantar flexion against a treadle at a frequency of one (s-1 to volitional fatigue), the muscle $\mathrm{Pi} / \mathrm{PC}$ ratio increases to a smaller extent in children than in adults, even when the data were normalised for body size. In the same study, the children show a smaller drop in intra-muscular $\mathrm{pH}$ than the adults. During low intensity exercise, the initial increase in slope of $\mathrm{Pi} / \mathrm{PC}$ in relation to work rate (i.e. the slow phase of $\mathrm{Pi} / \mathrm{PC}$ increase and $\mathrm{pH}$ decrease) is similar for both children and adults (i.e. similar mitochondrial oxidation rates). However, as the work rate increased, $75 \%$ of the adults and $50 \%$ of the children demonstrated a fast phase of $\mathrm{Pi} / \mathrm{PC}$ increase and $\mathrm{pH}$ decrease. These data seem to suggest that during high intensity exercise, children are more dependent than adults on oxidative phosphorylation, and are less reliant on anaerobic metabolism for the regeneration of ATP. Invariably, because 
only small numbers of children of different ages, gender, developmental and training levels were studied, coupled with the pooling of male and female data for both children and adults, which may be inappropriate because they are discrete populations (Armstrong \& Welsman, 1997), generalisations, if any, must be made with caution

Biochemical substrate level comparisons following exercise in young people and in adults may be flawed because they do not take into account changes in plasma volume. It is well known that blood volume is altered in response to physical exercise (Convertino et al, 1991) and the magnitude and direction of the response appears to be different in adults and in children (Macek et al, 1976). Plasma volume in children increases during exercise, in contrast to the plasma decrease in adults (Macek et al, 1976), and the magnitude of change in the opposite direction amounted to $10 \%$ but there is evidence to the contrary. For example, Hebestreit et al (1994) reported that plasma volume decreased in both pre-pubertal boys $(\mathrm{N}=5$; mean age 9.6y.) and men ( $N=5$; mean age 24.9y.), following a 30-second WAnT, but a significantly greater decrease is detected in the men (16.8\% versus $11.2 \%)$. This finding implies that post-exercise blood metabolites in adults are more concentrated than in young children. Consequently, child-adult comparisons of biochemical parameters made without respect to the change of plasma volume are therefore potentially erroneous.

\section{Glycolytic Enzyme Activities as Factors Affecting Maximal Intensity Exercise of Young People}

Research on the muscle metabolism of children is scant and there are very few studies on children which report on the enzyme systems involved in anaerobic metabolism. The most cited study is that of Eriksson (1972), some 30 years ago. $\mathrm{He}$ analysed muscle biopsy samples from the quadricep femoris in three groups of normal boys aged between 11 and 15 years. The activities of aerobic enzymes succinate dehydrogenase (SDH) and the anaerobic enzyme phosphofructokinse (PFK) were used as markers of aerobic and anaerobic function respectively. His results showed that in comparison to similar markers used in untrained men aged between 24 and 52 years, the mean SDH activity was 33\% higher in the boys whilst the mean PFK activity was 30\% lower in the boys than in the adult men. This is in agreement with the view articulated by Bale et al (1992), which suggests an inverse relationship between SDH and PFK activity, whereby a decrease in PFK activity is counter-balanced by a proportional increase in SDH activity and therefore oxidative phosphorylation. This inverse relationship between the activity of aerobic and anaerobic enzymes is consistent with the relationships observed between size and metabolic function in animals, where anaerobic fitness increases with animal size whilst aerobic fitness decreases (Hochachka, 1990). Seemingly in support of these ideas, higher than adult levels of oxidative enzymes such as succinic dehydrogenase (SDH) and isocitric dehydrogenase (ICDH) are reported in children and adolescents (Haralambie, 1982; Berg et al, 1986; Fournier et al, 1982). In the study of Berg et al (1986), the muscle enzyme activities, from resting quadriceps muscles in children four to eight, 12-14 and 16-18 years old were compared. Activity of PFK and other glycolytic enzymes rose progressively with increasing age but over the same age span, the activity of the aerobic enzymes also declined. The muscle activity ratio of aerobic and anaerobic enzymes was examined in the three age groupings. The ratio was 0.52 in the youngest age group, 0.27 in the $12-14$ years age group and 0.24 in the oldest age group. In support, Haralambie (1982) who examined the aerobic and anaerobic enzyme activities of the vastus lateralis from muscle biopsies of 13-15 year old adolescents and 22-42 year old adults also reported higher mean aerobic enzyme activities in the adolescents but no significant differences in glycolytic enzyme activities. The results suggest three possible scenarios, as children got older: (a) the activities of aerobic and anaerobic enzymes both increase but anaerobic enzyme activity increases more than that of the aerobic enzymes; (b) the activity of aerobic enzymes decrease with that of anaerobic enzymes remaining unchanged or (c) the activity of aerobic enzymes decrease with an increase in the activity of anaerobic enzymes. Current data are inadequate to discern which scenario is true. Based on the limited data available, it appears that young people have different enzyme activity patterns than those reported in adults. It is logical therefore to expect that children will best utilise what they are best equipped with, metabolically and physiologically, to cope with any exercise demand, particularly at high exercise intensities. It can be expected that adults will respond differently to children to the same relative exercise demand, at high intensity levels. Because data on muscle enzyme activity in young people are limited, Sargeant (1989) cautions that biopsy results are based on enzyme activity measured in vitro under optimal conditions, which may differ if it were assessed in vivo. Additionally, it must be stressed that muscle enzyme activity data are based on rest values, which may be different during exercise. Clearly, the issue of muscle enzyme activity during exercise has not been addressed. Moreover, not all the evidence is incontestable. In contrast to the earlier findings of Eriksson (1972), histochemical studies during different periods in the lives of animals and humans show that, at the end of the neonatal period, the level of the glycolytic potential 
(with evaluated PFK activity used as a marker) is close to that reported in the adult muscle (Colling-Saltin, 1980). The evidence is seemingly supported in experimental performance terms. For example, in electrical stimulation studies on children, muscle function that included an index of fatigue is similar to those of adults, when the results were normalised for body dimensions (Davies et al, 1983; Davies, 1985).

Perhaps the reasons for children's reduced fitness in maximal intensity exercise do not pivot on the levels and activity of glycolytic enzymes alone, other attributable factors may play a more important role in their anaerobic fitness. This was demonstrated indirectly by the results of Eriksson et al (1980). The investigators did not detect any glycolytic potential difference in patients with different types of congenital heart disease and in well trained individuals, suggesting that factors other than glycolytic potential, accounted for differences in anaerobic performance. It appears therefore that there is yet no conclusive evidence that confirms an age-dependent difference in the potential maximal rate of anaerobic glycolysis between children and adults. Further research using non-invasive techniques such as MRS during dynamic exercise may further clarify the matter.

\section{Lactate Kinetics as Factors Affecting Maximal Intensity Exercise of Young People}

Many researchers report lower lactate values attained by children during exercise (Macek, 1986), and immediately following maximal exercise (Fournier et al, 1982). Eriksson (1980) reported that muscle lactate immediately after maximal exercise is $11 \mathrm{mM} . \mathrm{L}^{-1}$ in 13.5-14.8 year old boys compared to $17 \mathrm{mM} . \mathrm{L}^{-1}$ in young adults. Additionally, Matejkova et al (1980), and Kindermann et al (1975), reported that between eight and 18 years of age, there appears to be a decline of 0.01 to $0.02 \mathrm{pH}$ units per year, in the ability to tolerate acidosis. The corresponding decline in base excess is 1-1.5 mM.L -1 $^{-}$(Matejkova et al, 1980; Von Ditter et al, 1977). The majority of the studies have focused on male participants and notably scarce are data on girls and women, where the findings might equivocal in comparison to the data on boys and men.

Armstrong and Welsman (1994) alerted researchers to the potential pitfalls in the interpretation of post-exercise blood lactate values, which are dependent on a host of factors-such as site of sampling, timing of post-exercise blood sampling, method of blood preparation prior to analysis, and the type of lactate analyser used. For example, Cumming et al (1980) noted that children could attain peak serum lactate levels, similar to adult values, if their motivation during the exercise was adequate. On closer scrutiny, Cumming et al (1980) reported on serum lactate values, which according to the work of Armstrong and Welsman (1994) are about 37.5\% higher than whole blood lactate values. It is also prudent to use blood lactate values simply as one of a number of indicators of effort rather than as a metabolic marker of anaerobic metabolism.

It appears, that fit children are not deficient in their ability to produce lactate. Ilmarinen et al (1984) studied 240 children aged eight to 12 years that participated in a ski competition. Blood samples taken pre- and two to three minutes post-competition, showed that pre-pubertal boys $(\mathrm{N}=23)$ and girls $(N=22)$, aged eight to 10 years, are able to produce high lactate values (greater than nine mM.L ${ }^{-1}$, top placings in the eight to 10 years age category), with no gender difference observed ( $p>0.05)$. In another study, Suurnakki et al (1986), examined the anaerobic strain in children (40 girls and 39 boys; aged eight to 14 years) during a cross-country skiing competition (distances of one and a half to three $\mathrm{km}$ ). Post-competition capillary blood lactate concentrations (one to three minutes post-exercise) were remarkably high. The mean lactate concentration for the girls was $11.2 \mathrm{mM} . \mathrm{L}^{-1}$ (range of 7.8-14.2 mM.L.1 and that for boys was $10.1 \mathrm{mM} . \mathrm{L}^{-1}$ (range 4.6 - $12.7 \mathrm{mM} . \mathrm{L}^{-1}$. Interestingly, in all the age groupings (8y., $10 \mathrm{y} ., 12 \mathrm{y} .$, and $14 \mathrm{y}$.), the lactate concentrations were higher in the girls than in the boys with significant gender differences reported for the eight year old and 14-year-old age groups. The results of Suurnakki et al (1986) are interesting for several reasons. They show that eight to 10 year old children, especially girls were able to produce high blood lactate concentrations (in excess of nine mM. $\mathrm{L}^{-1}$ but less than $12 \mathrm{mM} . \mathrm{L}^{-1}$ after 10-12 minutes of high intensity ski exercise in a competition setting. The results, however are in contrast with previous laboratory-based studies that reported that the maximal lactate concentrations in children are at the levels of six to nine mM.L ${ }^{-1}$, following a bout of exhaustive exercise (Astrand \& Rodah, 1986; de Knecht \& Binkhorst, 1980). According to Cumming et al (1980), motivation is one of the central factors in all-out effort or maximal exercise efforts, and can therefore have a very marked impact on the success in laboratory testing. In the study of Cumming et al (1980), the wide range in lactate concentrations-4.9-14.1 mM.L $\mathrm{L}^{-1}$ in their youngest group of children, may be attributed to their different degrees of motivation toward giving their best efforts to the test, even though all of them were similarly encouraged. In the study of Suurnakki et al (1986), the competitive nature of the ski event, meant that motivation remained high among 
the competitors throughout the entire duration of the exercise. However, the range of lactate values, overall for the girls and boys were 7.8-14.2 mM.L $\mathrm{L}^{-1}$ and 4.6-12.7 mM.L $\mathrm{L}^{-1}$, respectively. It is not known if such an observed range of values reflected motivational capacity or physiological capacity, or a combination of both. Indeed, Hermansen (1971), suggested that strong motivation may produce higher lactate values in competition that in laboratory tests. In support, adult studies demonstrate that lactate concentrations can be increased during sub-maximal exercise and during maximal exercise (Spriet et al, 1988), by infusions of adrenaline, which stimulate glycogenolysis. A point of interest in the field study of Suurnakki et al (1986), is that in all the age-groupings from eight years to 14 years, the blood lactate concentrations are higher in the girls than in the boys, although the gender differences are only significant in the youngest and oldest age groups studied.

Chia (2001) reported that the blood lactate concentration after three 20s WAnT that were separated by a $45 \mathrm{~s}$ recovery period between sprints, obtained at three minutes post-exercise, were not significantly different between girls and women

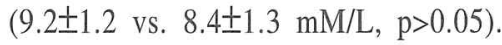

Most studies on normal active children show no gender difference in post-exercise lactate concentrations for similarly aged children, even when matched for maturational status (Armstrong \& Welsman, 1997). With reference to the study of Suurnakki et al (1986), it can be argued that, in the 14year-old group, the girls were more maturationally advanced than the similarly-aged boys and therefore, the alterations in enzyme activities, lactate kinetics and muscle mass, associated with puberty, can account for the higher lactate concentrations observed. Explanations were, however not put forward to account for the differences in lactate concentrations observed in the pre-pubertal age group. One can perhaps speculate that girls have a more adverse and pronounced response to catecholamines than boys, resulting in a greater accumulation of lactate for a similar relative exercise stimulus. However, further research is needed to elucidate the matter.

The interpretation of blood lactate concentrations is fraught with difficulties because it is the resultant of not only lactate production via anaerobic glycolysis of the muscle cell, but also its rate of release into the circulation, its distribution in total body water, and its removal and uptake by other tissues. As eloquently explained by Williams et al (1992), differences in the site of blood lactate sampling (arterial, venous or capillary; fingertip or earlobe), the assay medium employed (whole blood, plasma, serum or lysed) may influence the lactate result that is reported. Additionally, the timing of measurement of peak recovery lactate, sample handling and preservation, calibration and the type of lactate analysers, as well as analytical methods used may also account for differences that can be interpreted erroneously (Bishop \& Martino, 1993). For instance, most up-to-date lactate analysers assay lactate in the plasma portion of whole blood. However other analysers may require further blood preparations-chemical treatments that break down the red blood cells which release intracellular lactate into the mixture (lysed blood). Lactate in lysed blood is therefore higher than in whole blood, with the size of the difference being greater at higher concentrations $(5-10 \mathrm{mM})$ of lactate (Williams et al, 1992). Other methods of lactate analysis require that the blood be centrifuged, to separate the liquid portion of blood (plasma) from the cellular particles of blood, or clotted by the addition of chemical agents to derive serum, which are then assayed for lactate.

In adults, following incremental exercise to determine maximal oxygen uptake and very intense exercise, blood lactate peaks at about five minutes post-exercise (Rieu et al, 1988; Stegmann et al, 1981), whereas in children, possibly because of their smaller sizes (reduced diffusion distance between blood capillaries), peak blood lactate values are obtained one to two minutes post-exercise (Shephard et al, 1969). Shephard et al (1969) noted an earlier peaking of blood lactate concentrations in children. With adults, the lactate concentrations are similar, they noted, at two minutes and four minutes post exercise, whereas in comparison, the child values decrease from an average of $9.0 \mathrm{mM} . \mathrm{L}^{-1}$ at two minutes, to $8.1 \mathrm{mM} . \mathrm{L}^{-1}$ at four minutes and $7.8 \mathrm{mM} \cdot \mathrm{L}^{-1}$ at six minutes post exercise. Jacobs (1986) suggested that peak blood lactate evaluation following a maximal intensity exercise bout such as the WAnT could be obtained by sampling post-exercise, at one minute and continually at each minute up to six minutes. The rate of lactate release from active muscle to blood is maximal at muscle lactate concentrations of approximately $5 \mathrm{mM} . \mathrm{L}^{-1}$ in adults. Crielaard et al (1986a) reported that the maximal value of blood lactate after short duration tests is obtained not at the end of the exercise (Freund and Zoulouman, 1981), but at approximately 7.5 minutes of recovery. Fujitsuka et al (1982), proposed that peak lactate concentration after maximal exercise can be accurately predicted in adults based on a single blood sample taken at 7.65 minutes-a statistically derived time of appearance of peak value. However, it appears that peak lactate concentration after maximal exercise might be participant-specific and protocol dependent. Chia (2002) reported that using a maximal intermittent exercise protocol, which consisted of five $20 \mathrm{~s}$ WAnTs, separated by a $45 \mathrm{~s}$ recovery 
interval, men and women attained the highest lactate values by three and four minutes respectively, after the exercise bouts. This implies that generalisations about the timing of peak lactate attainment after exercise should be avoided. Of importance is that peak blood lactate values are reliable when the activity following the exercise bout is standardised (Fujitsuka et al, 1982). Lactate removal from the general circulation increases during active as opposed to passive recovery (Belcastro and Bonen, 1975).

It is important that investigators are consistent with the choice of the site of sampling, time of sampling, method of blood preparation and lactate analysis and the selection of a passive recovery period when the blood is being sampled. Failure to adhere to these proposed standardisation procedures lead to results that are difficult to interpret and reduce the meaningfulness of the data.

The reliability of post-exercise blood lactate concentration in adults is established. For instance, the coefficient of variation for a constant load test on a cycle ergometer ranges from 7.2\% (Fujitsuka et al, 1982) to $11 \%$ (Coggan \& Costill, 1984), and $11 \%$ for a 30-second isokinetic cycle bout (Coggan \& Costill, 1984). Moreover, the test-retest coefficient of correlation of peak blood lactate is high ( $r>0.9)$ for all-out effort tests (Crielaard et al, 1986a). However, Vandewalle et al (1987) pointed out that the reliability of post-exercise blood lactate concentrations is also dependent on the reliability of the ergometric tests inducing the lactate production.

There are very few related studies on children pertaining to the attainment of peak blood lactate values after a maximal exercise bout even though most studies report blood lactate values at two to three minutes (Ilmarinen et al, 1984) or three minutes (Williams, 1995) post-exercise. Lower blood lactate values reported for children after intense exercise may well be that if the blood is sampled at for example, three to five minutes post-exercise, which is common practice in most adult studies, then it can be expected that a substantial amount of lactate can be metabolised or cleared, hence giving a false lower reading for blood lactate in children. Work by Gaul et al (1995), with prepubertal boys aged 11.4 years, suggested that children's blood lactate values following a 90second maximal cycle sprint peak earlier than five minutes post-exercise $\left(9.1 \pm 1.7 \mathrm{mM} . \mathrm{L}^{-1}\right.$ at two min. vs. $8.2 \pm 14$ $\mathrm{mM} . \mathrm{L}^{-1}$ at five min., $\mathrm{p}<0.05$ ). In adolescents, post-exercise lactate kinetics is markedly different than those of adults who are engaged in similar intensity exercise. For example, Naughton et al (1993), examined the plasma lactate and ammonia responses in adolescent male athletes ( $N=7$; mean age 14.8y.) and adult male athletes $(\mathrm{N}=7$; mean age 19.6y.), following treadmill runs to exhaustion at $120 \%$ V02max. The authors reported that both plasma lactate and ammonia (venous blood samples) concentration levels are lower in adolescents than in adults, and the levels peak at three minutes in adolescents versus five minutes post-exercise in adults.

Chia (1997) reported that following a 30s WAnT, blood lactate concentration peaked by 2 minutes post-exercise in boys and girls using a 30s serial sampling protocol, but others have reported that in boys, peak lactate in blood is attained five minutes after a 30s WAnT (Dotan, Falk \& Daz, 2000).

Therefore it is plausible that in pre-pubertal children, because of their smaller sizes, blood lactate concentration values, after a bout of high intensity exercise may peak at earlier than three minutes after the exercise. Given that change in lactate is rapid, especially in children because of a smaller diffusion distance, the exact timing of blood draw becomes critical. Serial blood sampling at fixed intervals following allout intensity exercise will help elucidate the issue. Methodological artefact aside, if the postulations of Brooks (1985) on the dynamics of lactate accumulation are accepted, then the lower increase in lactate in children, compared to adults, during exercise, may simply reflect a difference in the imbalance of their rates of production and clearance from the blood, probably because of reduced blood flow to the liver, during non-steady state exercise. It is not known, if given the same metabolic environment, whether the rates of lactate production in children are similar to those of adults, but there is some research evidence to support that children have superior rates of lactate clearance than adults. According to Armstrong et al (1995), the lower blood lactate normally observed in children can possibly be due to the smaller mass to blood volume ratio in children than in adults. Such a view has credence, especially since, as pointed out by Macek et al (1976) and Hebestreit et al (1994), children's plasma volume increases during exercise (leading to a dilution effect), in contrast to a reduction in plasma volume that has been detected in adults (Boulay et al, 1995; Whittlesey et al, 1996). Whittlesey and colleagues reported that following a 30s WAnT, plasma volume in adult subjects decreased nearly $20 \%$. In body composition studies involving large samples of children across the maturity stages (Tanner stages 1 to 5) in a three year study, Slaughter et al, (1988), pointed out that body water in pre-pubertal children is $2.8 \%$ higher $(75.2 \%$ vs. $72.5 \%)$ than in adults. Additionally, Lohman, (1985) and Haschke et al (1983), collectively demonstrated that there are gender and age variations 
in total body water content throughout the maturity span of pre-pubescence to adulthood.

Studies which employ radioactive isotope tracers to monitor lactate turnover in adults, show that lactate concentration, as a consequence of high intensity exercise, is only partially explained by increases in lactate production (Brooks, 1991; Stanley et al, 1986). Therefore, it is difficult to state categorically that the production of lactate in children is inferior to that of adults, simply based on the evidence of relative blood lactate accumulation after high intensity exercise. The issue of lactate clearance in both adults and children must first be addressed before the matter can be clarified. Perhaps an alternative approach to expressing blood lactate values following maximal intensity exercise is necessary if examiners wish to make valid comparisons between adults' and children's performance in anaerobic tests. For instance, the blood lactate values can be expressed in relation to the amount of anaerobic work done, if one knew the extent of aerobic contribution towards the predominantly anaerobic test for both adults and children. However, it is noted that currently, computations of aerobic contribution to high intensity exercise are based on informed conjecture and assumptions, which remain difficult to verify. Table 2 provides an overview of the recent studies that report on blood lactate values after a bout of maximal intensity exercise, compiled from a literature search.

Table 2. Blood Lactate Concentration after Maximal Intensity Exercise.

\begin{tabular}{|c|c|c|c|c|}
\hline Author \& Year & Subjects & $\begin{array}{c}\text { Exercise } \\
\text { bout }\end{array}$ & $\begin{array}{l}\text { Site \& time of } \\
\text { sampling post- } \\
\text { exercise } \\
\text { [min] }\end{array}$ & $\begin{array}{l}\text { Peak blood lactate } \\
\text { concentration } \\
{\left[\mathrm{mM} \cdot \mathrm{L}^{-1} \pm \mathrm{S} . \mathrm{D}\right]}\end{array}$ \\
\hline $\begin{array}{c}\text { Van Praagh et al } \\
(1989)\end{array}$ & $\begin{array}{l}19,7.4 \text {-year- } \\
\text { old boys }\end{array}$ & $\begin{array}{l}\text { 30-second } \\
\text { WAnT }\end{array}$ & $\begin{array}{c}\text { Ear-lobe, } \\
\text { several samples } \\
\text { between 1- } 5 \\
\text { min }\end{array}$ & $7.0 \pm 3.2$ \\
\hline \multirow[t]{4}{*}{ Mero (1988) } & $\begin{array}{c}19,12.6 \text {-year- } \\
\text { old athletic } \\
\text { boys }\end{array}$ & $\begin{array}{l}\text { 15-second } \\
\text { WAnT }\end{array}$ & $\begin{array}{l}\text { Finger tip } 5 \\
\text { minutes post- } \\
\text { WAnT }\end{array}$ & $9.3 \pm 2.0$ \\
\hline & $\begin{array}{l}\text { Six, 11.9-year- } \\
\text { old boys } \\
\text { (control) }\end{array}$ & $\begin{array}{l}\text { 15-second } \\
\text { WAnT }\end{array}$ & $\begin{array}{l}\text { Finger tip } 5 \\
\text { minutes post- } \\
\text { WAnT }\end{array}$ & $8.5 \pm 1.5$ \\
\hline & $\begin{array}{c}19,12.6 \text {-year- } \\
\text { old athletic } \\
\text { boys }\end{array}$ & $\begin{array}{l}\text { 60-second } \\
\text { WAnT }\end{array}$ & $\begin{array}{l}\text { Finger tip } 5 \\
\text { minutes post- } \\
\text { WAnT }\end{array}$ & $13.1 \pm 2.6$ \\
\hline & $\begin{array}{c}\text { Six, 11.9-year- } \\
\text { old boys } \\
\text { (control) }\end{array}$ & $\begin{array}{l}\text { 60-second } \\
\text { WAnT }\end{array}$ & $\begin{array}{c}\text { Finger tip } 5 \\
\text { minutes post- } \\
\text { WAnT }\end{array}$ & $12.8 \pm 2.3$ \\
\hline \multirow[t]{2}{*}{$\begin{array}{l}\text { Ilmarinen et al } \\
\text { (1984) }\end{array}$} & $\begin{array}{l}240,8-12 \text { year- } \\
\text { old boys and } \\
\text { girls }\end{array}$ & $\begin{array}{c}\text { Ski- } \\
\text { competition. } \\
\text { Distance } 1.5 \\
-3 \mathrm{~km} \\
\end{array}$ & $\begin{array}{l}\text { Finger tip } 2-3 \\
\text { min post } \\
\text { competition }\end{array}$ & $\begin{array}{l}\text { Boys }-6.5 \\
\text { (mean) } \\
\text { Girls - 6.0 } \\
\text { (mean) }\end{array}$ \\
\hline & $\begin{array}{l}\text { Seven, } 8 \text { year- } \\
\text { old boys }\end{array}$ & $\begin{array}{c}\text { Ski- } \\
\text { competition. } \\
1.5 \mathrm{~km} \\
\end{array}$ & $\begin{array}{c}\text { Finger tip } 2-3 \\
\text { min post } \\
\text { competition }\end{array}$ & $6.86 \pm 2.40$ \\
\hline & $\begin{array}{l}\text { Four, 8-year- } \\
\text { old girls }\end{array}$ & $\begin{array}{c}\text { Ski- } \\
\text { competition. } \\
1.5 \mathrm{~km}\end{array}$ & $\begin{array}{c}\text { Finger tip } 2-3 \\
\text { min post } \\
\text { competition }\end{array}$ & $5.6 \pm 3.1$ \\
\hline & $\begin{array}{l}\text { Seven, } 10 \text {-year- } \\
\text { old boys }\end{array}$ & $\begin{array}{c}\text { Ski- } \\
\text { competition. } \\
2 \mathrm{~km} \\
\end{array}$ & $\begin{array}{l}\text { Finger tip } 2 \text { - } 3 \\
\text { min post } \\
\text { competition }\end{array}$ & $6.3 \pm 1.9$ \\
\hline & $\begin{array}{l}\text { Six, 10-year- } \\
\text { old girls }\end{array}$ & $\begin{array}{c}\text { Ski- } \\
\text { competition. } \\
2 \mathrm{~km} \\
\end{array}$ & $\begin{array}{c}\text { Finger tip } 2-3 \\
\text { min post } \\
\text { competition }\end{array}$ & $6.0 \pm 2.2$ \\
\hline
\end{tabular}


Table 2. Blood Lactate Concentration after Maximal Intensity Exercise. (Continued)

\begin{tabular}{|c|c|c|c|c|}
\hline Author \& Year & Subjects & $\begin{array}{c}\text { Exercise } \\
\text { bout }\end{array}$ & $\begin{array}{l}\text { Site \& time of } \\
\text { sampling post- } \\
\text { exercise } \\
\text { [min] }\end{array}$ & $\begin{array}{l}\text { Peak blood lactate } \\
\text { concentration } \\
{\left[\mathrm{mM} \bullet \mathrm{L}^{-1} \pm \mathrm{S} . \mathrm{D}\right]}\end{array}$ \\
\hline & $\begin{array}{l}\text { Seven, 12-year- } \\
\text { old boys }\end{array}$ & $\begin{array}{c}\text { Ski- } \\
\text { competition. } \\
3 \mathrm{~km} \\
\end{array}$ & $\begin{array}{c}\text { Finger tip } 2-3 \\
\text { min post } \\
\text { competition }\end{array}$ & $6.4 \pm 1.9$ \\
\hline & $\begin{array}{l}\text { Six, 12-year- } \\
\text { old girls }\end{array}$ & $\begin{array}{c}\text { Ski- } \\
\text { competition, } \\
3 \mathrm{~km}\end{array}$ & $\begin{array}{c}\text { Finger tip } 2=3 \\
\text { min post } \\
\text { competition }\end{array}$ & $6.26 \pm 0.7$ \\
\hline & $\begin{array}{l}\text { Three, top } \\
\text { placings for } \\
\text { boys and girls } \\
\text { in each age } \\
\text { group. }\end{array}$ & $\begin{array}{c}\text { Ski- } \\
\text { competition. } \\
1.5-3 \mathrm{~km}\end{array}$ & $\begin{array}{c}\text { Finger tip } 2-3 \\
\text { min post } \\
\text { competition }\end{array}$ & $\begin{array}{c}\text { 8-year-olds: } \\
\text { Boys - } 9.4 \\
\text { Girls - } 9.2 \\
\text { 10-year-olds: } \\
\text { Boys - 8.9; } \\
\text { Girls - 8.7 } \\
\text { 12-year-olds: } \\
\text { Boys - 9.6; } \\
\text { Girls - 6.8 }\end{array}$ \\
\hline \multirow[t]{3}{*}{ Mero (1991) } & $\begin{array}{l}\text { Eighteen } 11.6 \\
\text { year-old } \\
\text { athletes: } \\
\text { weight-lifters, } \\
\text { tennis players, } \\
\text { endurance } \\
\text { runners, } \\
\text { sprinters, plus } 6 \\
\text { non-athletic but } \\
\text { active boys } \\
\end{array}$ & $\begin{array}{l}60 \text {-second } \\
\text { all-out cycle } \\
\text { test }\end{array}$ & $\begin{array}{l}\text { Unspecified } \\
\text { sampling site-5 } \\
\text { min into } \\
\text { recovery }\end{array}$ & $9.4 \pm 2.5$ \\
\hline & $\begin{array}{c}18,13.6 \text { year- } \\
\text { old athletic } \\
\text { boys :same } \\
\text { group, } 2 \text { years } \\
\text { later }\end{array}$ & $\begin{array}{l}60 \text {-second } \\
\text { all-out cycle } \\
\text { test }\end{array}$ & Unspecified & $13.3 \pm 3.3$ \\
\hline & $\begin{array}{c}\text { Six, } 13.6 \text { year- } \\
\text { old non-athletic } \\
\text { but active boys: } \\
\text { same group of } \\
\text { active boys, } 2 \\
\text { years later }\end{array}$ & $\begin{array}{l}\text { 60-second } \\
\text { all-out cycle } \\
\text { test }\end{array}$ & Unspecified & $12.2 \pm 1.1$ \\
\hline \multirow[t]{5}{*}{$\begin{array}{c}\text { Falgairette et al } \\
\text { (1991) }\end{array}$} & $\begin{array}{c}36,6-8 \text {-year- } \\
\text { old boys }\end{array}$ & $\begin{array}{l}\text { 30-second } \\
\text { WAnT }\end{array}$ & $\begin{array}{c}\text { Ear-lobe, } 2 \mathrm{~min} \\
\text { post-exercise }\end{array}$ & $6.2 \pm 2.1$ \\
\hline & $\begin{array}{l}27,9-10 \text {-year- } \\
\text { old boys }\end{array}$ & $\begin{array}{l}\text { 30-second } \\
\text { WAnT }\end{array}$ & $\begin{array}{l}\text { Ear-lobe, } 2 \mathrm{~min} \\
\text { post-exercise }\end{array}$ & $5.1 \pm 1.8$ \\
\hline & $\begin{array}{c}\text { 34, 11-12-year- } \\
\text { old boys }\end{array}$ & $\begin{array}{l}\text { 30-second } \\
\text { WAnT }\end{array}$ & $\begin{array}{c}\text { Ear-lobe, } 2 \mathrm{~min} \\
\text { post-exercise }\end{array}$ & $7.7 \pm 2.1$ \\
\hline & $\begin{array}{c}29,13 \text {-year-old } \\
\text { boys }\end{array}$ & $\begin{array}{l}\text { 30-second } \\
\text { WAnT }\end{array}$ & $\begin{array}{l}\text { Ear-lobe, } 2 \mathrm{~min} \\
\text { post-exercise }\end{array}$ & $8.4 \pm 2.1$ \\
\hline & $\begin{array}{c}18,14-15 \text {-year- } \\
\text { old boys }\end{array}$ & $\begin{array}{l}\text { 30-second } \\
\text { WAnT }\end{array}$ & $\begin{array}{c}\text { Ear-lobe, } 2 \mathrm{~min} \\
\text { post-exercise }\end{array}$ & $7.8 \pm 1.6$ \\
\hline \multirow[t]{2}{*}{ Duche et al ( 1992 ) } & $\begin{array}{c}13,9.29 \text {-year- } \\
\text { old prepubertal } \\
\text { boys }\end{array}$ & $\begin{array}{l}\text { 30-second } \\
\text { WAnT }\end{array}$ & $\begin{array}{l}\text { Ear-lobe } 2-3 \\
\text { min post-WAnT }\end{array}$ & $4.2 \pm 1.4$ \\
\hline & $\begin{array}{c}13,10.5 \text {-year- } \\
\text { old prepubertal } \\
\text { boys }\end{array}$ & $\begin{array}{l}\text { 30-second } \\
\text { WAnT }\end{array}$ & $\begin{array}{c}\text { Ear-lobe } 2-3 \\
\text { min post-WAnT }\end{array}$ & $6.6 \pm 1.5$ \\
\hline
\end{tabular}


Table 2. Blood Lactate Concentration after Maximall Intensity Exercise. (Continued)

\begin{tabular}{|c|c|c|c|c|}
\hline Author \& Year & Subjects & $\begin{array}{c}\text { Exercise } \\
\text { bout }\end{array}$ & $\begin{array}{c}\text { Site \& time of } \\
\text { sampling post- } \\
\text { exercise } \\
\text { [min] }\end{array}$ & $\begin{array}{c}\text { Peak blood lactate } \\
\text { concentration } \\
{\left[\mathrm{mM} \cdot \mathrm{L}^{-1} \pm \mathrm{S} . \mathrm{D}\right]}\end{array}$ \\
\hline & $\begin{array}{c}13,11.2 \text {-year- } \\
\text { old prepubertal } \\
\text { boys }\end{array}$ & $\begin{array}{l}\text { 30-second } \\
\text { WAnT }\end{array}$ & $\begin{array}{c}\text { Ear-lobe } 2-3 \\
\text { min post-WAnT }\end{array}$ & $6.5 \pm 1.5$ \\
\hline & $\begin{array}{c}\text { 13, 12.1-year- } \\
\text { old pubertal } \\
\text { boys }\end{array}$ & $\begin{array}{l}\text { 30-second } \\
\text { WAnT }\end{array}$ & $\begin{array}{c}\text { Ear-lobe } 2-3 \\
\text { min post-WAnT }\end{array}$ & $7.9 \pm 1.5$ \\
\hline & $\begin{array}{c}13,14.3 \text {-year- } \\
\text { old pubertal } \\
\text { boys }\end{array}$ & $\begin{array}{l}\text { 30-second } \\
\text { WAnT }\end{array}$ & $\begin{array}{c}\text { Ear-lobe } 2 \text { - } 3 \\
\text { min post-WAnT }\end{array}$ & $10.0 \pm 1.3$ \\
\hline \multirow[t]{3}{*}{$\begin{array}{c}\text { Falgairette et al } \\
\text { (1994) }\end{array}$} & $\begin{array}{l}26,11.3 \text {-year- } \\
\text { old swimmers }\end{array}$ & $\begin{array}{l}\text { 30-second } \\
\text { WAnT }\end{array}$ & $\begin{array}{c}\text { Ear-lobe, } 2 \\
\text { minutes post } \\
\text { exercise }\end{array}$ & $8.0 \pm 1.8$ \\
\hline & $\begin{array}{l}16,11.3 \text {-year- } \\
\text { old active boys }\end{array}$ & $\begin{array}{l}\text { 30-second } \\
\text { WAnT }\end{array}$ & $\begin{array}{c}\text { Ear-lobe, } 2 \\
\text { minutes post } \\
\text { exercise }\end{array}$ & $7.9 \pm 2.5$ \\
\hline & $\begin{array}{c}\text { 11, 11.0-year- } \\
\text { old non-active } \\
\text { boys }\end{array}$ & $\begin{array}{l}\text { 30-second } \\
\text { WAnT }\end{array}$ & $\begin{array}{l}\text { Ear-lobe, } 2 \\
\text { minutes post } \\
\text { exercise }\end{array}$ & $6.9 \pm 1.7$ \\
\hline Gaul et al (1995) & $\begin{array}{c}18,11.4 \text {-year- } \\
\text { old physically } \\
\text { active } \\
\text { prepubertal } \\
\text { boys } \\
\end{array}$ & $\begin{array}{l}90 \text {-second } \\
\text { supra- } \\
\text { maximal } \\
\text { cycle sprint }\end{array}$ & $\begin{array}{c}\text { Finger tip, } 2 \\
\text { minutes and } 5 \\
\text { minutes post } \\
\text { exercise }\end{array}$ & $\begin{array}{c}2 \text { minutes } \\
9.1 \pm 1.7 \\
5 \text { minutes } \\
8.2 \pm 1.4\end{array}$ \\
\hline $\begin{array}{l}\text { Hebestreit et al } \\
\text { (1994) }\end{array}$ & $\begin{array}{c}\text { Five, 9.6-year- } \\
\text { old prepubertal } \\
\text { boys }\end{array}$ & $\begin{array}{l}\text { 30-second } \\
\text { WAnT }\end{array}$ & $\begin{array}{c}\text { Unspecified } 10 \\
\text { min post-WAnT }\end{array}$ & $\begin{array}{c}5.7 \pm 0.7 \\
\text { (plasma lactate) }\end{array}$ \\
\hline \multirow[t]{2}{*}{ Williams et al (1994) } & $\begin{array}{c}97,12.3-\text { year- } \\
\text { old boys }\end{array}$ & $\begin{array}{l}\text { 30-second } \\
\text { WAnT }\end{array}$ & $\begin{array}{c}\text { Finger-tip, } 3 \\
\text { min post-WAnT }\end{array}$ & $6.62 \pm 1.36$ \\
\hline & $\begin{array}{c}88,12.5 \text {-year- } \\
\text { old girls } \\
\end{array}$ & $\begin{array}{l}\text { 30-second } \\
\text { WAnT }\end{array}$ & $\begin{array}{c}\text { Finger-tip, } 3 \\
\text { min post-WAnT } \\
\end{array}$ & $5.9 \pm 1.1$ \\
\hline \multirow[t]{2}{*}{ Williams (1995) } & $\begin{array}{c}20,13.1 \text {-year } \\
\text { old boys }\end{array}$ & $\begin{array}{l}\text { 30-second } \\
\text { WAnT } \\
\end{array}$ & $\begin{array}{c}\text { Finger-tip, } 3 \\
\text { min post-WAnT } \\
\end{array}$ & $6.0 \pm 2.3$ \\
\hline & $\begin{array}{c}20,13.1 \text {-year- } \\
\text { old girls }\end{array}$ & $\begin{array}{l}\text { 30-second } \\
\text { WAnT }\end{array}$ & $\begin{array}{c}\text { Finger-tip, } 3 \\
\text { min post-WAnT }\end{array}$ & $\begin{array}{l}4.4 \pm 1.4 \\
\end{array}$ \\
\hline Chia et al (1997) & $\begin{array}{l}25,9.7 \text {-year- } \\
\text { old boys; } \\
25,9.7 \text {-year- } \\
\text { old boys }\end{array}$ & $\begin{array}{l}\text { 30-second } \\
\text { WAnT }\end{array}$ & $\begin{array}{c}\text { Serial finger-tip, } \\
\text { at } 30 \text { s intervals, } \\
\text { post-WAnT. } \\
\text { Peak attained } \\
\text { by } 2 \text { minutes) }\end{array}$ & $\begin{array}{l}\text { Mean of } 3.6 \\
\text { in boys } \\
\text { Mean of } 4.9 \\
\text { in girls }\end{array}$ \\
\hline Chia (2001) & $\begin{array}{l}19,13.6 \text {-year- } \\
\text { old girls } \\
21,25.1 \text {-year } \\
\text { old women }\end{array}$ & $\begin{array}{l}\text { Three } 15 \mathrm{~s} \\
\text { WAnT, } \\
\text { separated by } \\
45 \mathrm{~s} \text { active } \\
\text { recovery } \\
\text { between } \\
\text { sprints }\end{array}$ & $\begin{array}{l}\text { Finger-tip, } 3 \\
\text { minutes post- } \\
\text { WAnTs }\end{array}$ & $\begin{array}{c}9.2 \pm 1.2 \text { in girls } \\
8.4 \pm 1.3 \text { in women }\end{array}$ \\
\hline Chia et al (2002) & $\begin{array}{l}16,15.5 \text {-year- } \\
\text { old boys with } \\
\text { moderate } \\
\text { intellectual } \\
\text { disability }\end{array}$ & $\begin{array}{l}\text { 30-second } \\
\text { WAnT }\end{array}$ & $\begin{array}{l}\text { Finger-tip, } 3 \\
\text { minutes post- } \\
\text { WAnT }\end{array}$ & $3.8 \pm 2.2$ \\
\hline
\end{tabular}




\section{Sympathetic Activity as a Factor Affecting Maximal Intensity Exercise of Young People}

The activity of the sympathoadrenal system increases in relation to the workload (Naveri, 1985) and the catecholamine level rises because noradrenaline is released from sympathetic nerve endings in the muscle (Savard et al, 1987). Catecholamines can increase glycolysis and lactate production. This is clearly demonstrated by the increased muscle and blood lactate at rest during infusions of adrenaline (Chasiotis et al, 1983). Additionally, Galbo (1983) reported that the exponential increase in muscle lactate for exercise workloads in excess of $50 \%$ V02max, is also associated with an increased level of plasma catecholamines.

In children and adults, the relationship between adrenaline and glycolysis, with subsequent lactate accumulation is well argued and accepted (Macek, 1986; Mazzeo \& Marshall, 1989; Stainsby, 1986). For instance, Rowland et al (1995) examined the relationship between plasma lactate and adrenaline during incremental cycle exercise to exhaustion in 10-11-year-old boys $(\mathrm{N}=11)$. The investigators reported increases in blood lactate concentration values, which paralleled those of adrenaline ( $\mathrm{r}=$ 0.81 at peak $\mathrm{V}_{2}$ ), confirming a close association of plasma lactate and adrenaline in children during exercise.

Information on the changes in the production of catecholamines in the growing child is scant (Macek, 1986). It is thought that the catecholamines-adrenaline and noradrenaline -play an important role in muscle function especially toward force generation. The collective actions-both direct and indirectfor muscle function, as suggested by Kraemer (1992) include Increased force production, increased contraction rate, increased blood pressure, increased energy availability and the augmentation of secretion rates of other hormones (e.g. testosterone). Reports have suggested that plasma noradrenaline levels during exercise, as an indicator of sympathetic neurological activity, may be reduced in children in comparison to adults (Lehmann et al, 1981; Palmer et al, 1978) but there is contrary evidence in the cited literature (Koch, 1980; Rowland et al, 1996) In their earlier work, Lehmann et al (1981), did not report differences in peak catecholamine excretions during graded treadmill exercise at the same absolute work intensity in 12 year old boys and young adult men. Subsequently, when their data were recalculated for the same relative work intensities, the values for boys were lower, and about $30 \%$ lower after maximal exercise. Palmer et al (1978) reported that heart rate and blood pressure were less responsive to sympathetic provocation (i.e. standing position, isometric exercise) in 10 - 20 year old subjects compared with older adults.
Work by Rowland et al (1996) however provides some evidence that plasma nordrenaline levels at rest, during submaximal exercise and maximal cycling exercise are not different for boys and men. However, Rowland et al (1996) noted that maximal noradrenaline levels were nearly $16 \%$ greater in the adult men than in the boys $(1,385 \pm 612$ vs. $1,196 \pm 326$ pg. $\mathrm{mL}^{-1}$ ), and the adults increased their mean levels from rest to maximum by a factor of nearly 15 times compared with nearly 10 times for the boys. It is probable that the lack of statistical significant in the difference in noradrenaline levels at maximal exercise may be due to the large standard deviations in concentration values. Moreover, it can be speculated that at maximal exercise intensities, the difference in catecholamine levels between adults and children may be exacerbated.

Apparently a close relationship is established between the increase in circulating catecholamines and lactate, which in turn indicates a reduced maximal sympathetic activity in children (Macek, 1986). It is postulated that a reduced sympathetic activity during maximal exercise in children translates to a greater blood flow to the liver, which in turn, is able to remove lactate from the blood at higher rates than in adults. Such a postulation, advanced by Lehmann et al (1981) may help explain a lower lactate accumulation in the blood following maximal exercise in children.

\section{Hormonal Response as a Factor Affecting Maximal Intensity Exercise of Young People}

As children's maximal intensity exercise fitness increases with growth and maturity, the preferred explanation for some time, is that hormonal changes that mirror sexual maturation play a significant role in the regulation of glycolytic enzymes and their levels and rates of activity. Testosterone, in particular, a potent anabolic agent, is implicated as a significant contributor to the differences documented in musculature and strength performance between males and females. The evidence, it appears is equivocal. Researchers-Fellmann et al (1988), and Falgairette et al (1991)-identified a relationship between lactate production and salivary testosterone levels. In addition, Mero (1988), showed a relationship between lactic acid production and serum testosterone. Also studies on castrated animals by Bass et al (1971), Dux and Guba (1982), and Krotkiewski and his team (1980), all established a causal relationship between testosterone levels and glycolytic metabolism development, especially during puberty in male animals.

However, Paterson et al (1986), reported that anaerobic capacity and lactate concentrations measured during highintensity exercise are apparently unrelated to pubertal events, 
a finding supported and echoed by Welsman and Armstrong (1996; Armstrong et al, 1997) that dealt with submaximal and maximal lactate measures. Armstrong and Welsman (1997) refuted the argument that the glycolytic ability of children is dependent on sexual maturity. Working with child subjects, they noted that blood lactate responses during peak oxygen uptake determination, remained consistent across the full age and maturity range (Tanner stages 1 to 5 ). The data were generated from 100 boys and 100 girls (Tanner stage 1 to 4 , inclusive) showed that when body mass are adjusted for, testosterone made no significant additional contribution to the explained variance of peak and mean power outputs. In support, Winter (1978), pointed out that differences in strength performance between the sexes with age before puberty are probably independent of sex steroid influences, since the circulating levels increase only slightly during childhood and the midchildhood years, and are not different in both boys and girls. The view of Winter (1978) is in collusion with a review study by Armstrong and Welsman (1994) that highlighted that although testosterone levels in pre-pubertal and pubertal girls are very low, their ability to produce lactate is not compromised. In fact in some studies, the anaerobic performances of prepubertal and pubertal girls are significantly better than those of boys of the same age (Naughton \& Carlson, 1992; Suurnakki et al, 1986). Bar-Or (1983), suggested that it is premature to assume that differences in glycolytic ability between boys and men are explained by differences in the male hormone activity. The notable failure of investigators to address girls' anaerobic ability despite low testosterone levels suggests that the hormone plays a less critical role than previously speculated, in the development and maturation of glycolytic ability.

Testosterone, besides being the most active stimulator of muscle-building activities, is also known as a regulator of neurotransmitter release (Soucer et al, 1982) and a stimulator in the conversion of muscle fibre types (Kelly et al, 1985) in rodent experiments. It is not known if testosterone exerts a similar non-anabolic effect on human skeletal muscle. Apart from testosterone, growth and thyroid hormones, which also influence muscle growth may also help explain the evolution of anaerobic performance.

\section{Neuromotor Response as a Factor Affecting Maximal Intensity Exercise of Young People}

According to Thomas and Nelson (1990), the ability to generate power is not only dependent on the combined effects of strength and speed but, more importantly, it is dependent on the skilful co-ordination of strength and speed. Child-adult differences in anaerobic fitness may reflect more of qualitative, rather than a quantitative difference in the child's ability to generate power. Therefore neuromuscular differences such as motor unit recruitment patterns, and the differences in the degree and extent of myelination of the nervous system (Wilmore \& Costill, 1994), in the child and the adult cannot be ruled out. Indeed, an improvement in the efficiency of contractile activity, with growth and maturity (which also mirror those observed with training) can be suggestive of a neurogenic response, perhaps preceding the myogenic adaptation of muscle, in the ability to generate power. For instance, Westra et al (1985) demonstrated such a neurogenic response in rodents. Therefore to search only for metabolic explanations to explain differences in performance between subjects at different stages of development, may be somewhat myopic. It is established that in vivo voluntary force development in muscle is highly dependent upon the degree of motor unit activation (Belanger \& McComas, 1981; Komi, 1979, 1984). In turn, the degree of motor unit activation is dependent upon both the level of voluntary neural drive (number of motor units recruited) and the level of activation (discharge frequency) of the recruited motor units (Blimkie, 1989).

Since motor unit activation is the antecedent of force development in muscle, it is possible therefore that some of the documented variability in skeletal muscle strength and anaerobic leg performance may be explained by age and genderassociated differences in the ability to activate muscle. Brooks and Fahey (1984) noted that the extent of development of strength and performance capability of muscle is dependent on the relative maturation of the nervous system. Indeed, high levels of strength, power and skill are impossible if the child does not attain neural maturity. Myelination of many motor nerves is incomplete until sexual maturation, therefore the neural control of muscle is incomplete until that time (Wilmore \& Costill, 1994). Based on dimensional theory, Asmussen and Heebol-Nielsen (1955), reported that short young girls and boys (from a sample of children aged 7-16 years) are unable to produce the predicted muscle power that correspond to height squared. In the same study, they found that young boys achieved their predicted strength potential at an earlier age than girls. The authors explained that the poorer-thanexpected strength performance of the children could be attributed to their inability to fully activate their muscles during the voluntary strength test. These early observations lend support to the existence of age-, sex- and size-associated differences in the ability to activate the neuromuscular system during voluntary strength performance. Further insight into children's ability to fully activate their muscles during voluntary exercise 
is provided by means of the twitch interpolation technique (Belanger \& McComas, 1981). However such a technique has only been applied to isometric exercise involving small groups of children. For example, Blimkie (1989), used such an approacha supra-maximal electrical stimulation is applied to the active muscle during maximal voluntary isometric muscle contraction; any increase in the elicitation of force implies a failure to fully activate the muscle voluntarily-and applied it to the elbow flexor and knee extensor groups of muscles in 10 - 16 year old males. No age-associated difference in the ability to fully activate the active muscles is reported for the isometric elbowflexion task, but there are significant differences $(77.7 \%$ for 10 year olds versus $95.3 \%$ for 16 year olds) in the degree of motor-unit activation of the knee extensors. It is not known if there are sex-associated differences in children's neuromuscular activation abilities as the study focused only on boys. From the results of Blimkie (1989), one may conclude that there are differences in children's ability to fully activate their muscles that may vary across age, sex and muscle groups for voluntary isometric contractions. In another study, Asai and Aoki (1996) compared the force development capability of six-year-old boys in dynamic and static contractions of the elbow flexors with those of 24-year old men. The children generated lower maximum power than the adults $(22.8$ vs. $160.8 \mathrm{~W})$ and registered a lower rate of force development in the static contractions. The authors concluded that for both dynamic and static contractions, the contractile speed in children is lower than those of adults.

Anaerobic fitness in growing children is dependent in part (and acting in concert with other factors) on the neural motor adaptations that accompany growth and maturation. Some of these adaptations include the processes of myelination (Kraemer et al, 1989), increased muscle co-ordination between agonists and antagonists (Sale, 1989; Sargeant, 1989), and also the degree of motor unit activation (Blimkie, 1989). More effective transmission of power via connective tissue changes and increased mean transmission speed of the muscle can also account for improved power generating function of growing and maturing young people (Sargeant, 1989). These qualitative factors in the ability to generate force cannot be ruled out in accounting for children's anaerobic fitness.

\section{Oxygen Uptake Kinetics as Factors Affecting Maximal Intensity Exercise of Young People}

The characterisation of oxygen uptake kinetics during heavy exercise- exercise at an intensity that is above the anaerobic or lactate threshold- has not received much research attention until recently (Barstow, 1994; Poole, 1994; Whipp, 1994). The oxygen uptake kinetics of children during exercise, appear to be different from adults, but the existing evidence is equivocal. Some studies show that children have shorter oxygen uptake transients than adults (Armon et al, 1991; Barstow, 1994). Barstow (1994), showed that during heavy exercise, children demonstrated little or no slow component in oxygen uptake but instead, a gain in the fast component which is greater than that documented in adults i.e. a time delay that is less than 15-20 seconds. A study by Robinson (1938), reported that children reached $50 \%$ of peak $\mathrm{VO}_{2}$ during the first 30 seconds of a maximal treadmill test. At the same time, the adult values were around $30 \%$ of $\mathrm{V}_{2}$ max. Additionally, Macek and Vavra (1980) showed that acute maximum exercise (90$100 \%$ of maximal work rate for four to five minutes) induced a more rapid oxygen uptake increase in 10-11 year old boys in comparison to 20-22 year old men, suggesting that children recruit aerobic energy sources more quickly than adults, at the onset of maximal and supra-maximal exercise. The authors also suggested that perhaps children have greater oxygen content which is available at the start of exercise. In support of the view that children have shorter oxygen uptake transients than adults during heavy exercise, Freedson et al (1983) demonstrated that a positive relationship exists between age and the time taken to reach $50 \%$ of steady-state oxygen uptake.

There is however evidence to the contrary. For instance, Sady et al (1983), who examined child-adult comparisons of oxygen uptake and heart rate kinetics during sub-maximal exercise, reported that children and adults do not differ in cardiovascular adjustments during low intensity exercise (42\% of peak $\mathrm{VO}_{2}$ for children versus $39 \% \mathrm{VO}_{2}$ max for adults). It is possible that the oxygen kinetics of children may demonstrate an intensity-based pattern rather than a uniform response to exercise of different intensities. Indeed it is known that children's swifter attainment of steady-state at the onset of exercise as compared with adults is more apparent at exercise intensities above the anaerobic threshold (Armon et al, 1991), but less so at lower exercise intensities (Zanconato et al, 1991).

The faster oxygen kinetics of children finds support in the work of Bell et al (1980). Their study focused on the morphometric analysis of skeletal muscle, which employed the use of the needle biopsy technique, in 13, six-year-old Swiss children. The investigators found that, based on the relative volume densities of mitochondria and intracellular lipid, the six-year-old children, demonstrated an equivalent or slightly greater capacity for oxidative metabolism than sedentary adults. 
Welsman et al (2001) compared the respiratory responses of 21 adults and 21 children at the onset of non-steady state exercise and reported that the time constants for ventilation, oxygen uptake and carbon dioxide production were significantly shorter in children than in adults. These findings were corroborated by Fawker et al (2001) whose study examined the oxygen uptake kinetics in response to moderate intensity exercise in a group of adults and children. In the latter study, a significant correlation was obtained between the time constant and peak $\mathrm{VO}_{2}$ only in the male participants. This suggests that the mechanisms responsible for the shorter $\mathrm{VO}_{2}$ response to dynamic exercise in children than in adults may be independent from those that influence peak $\mathrm{VO}_{2}$.

Even though the swifter oxygen kinetics in children may help explain a reduced reliance on anaerobic metabolism (hence a smaller oxygen deficit and lactate accumulation), no precise mechanism is implicated to explain this apparent difference between children and adults. Moreover, whether the swifter oxygen uptake response to high intensity exercise is a natural characteristic of children, or whether it is a compensatory necessity for children's low glycolytic ability remains unresolved (Bar-Or, 1983). Some researchers offer a possible explanation that remains unverified-that the faster half-time of oxygen uptake observed in children is the result of a smaller body and the resultant shorter circulation time which can explain a swifter cardiovascular adjustment to exercise than adults (Cumming, 1978; Eriksson, 1972; Macek et al, 1976). Such an assertion is supported by the early German work of Helmreich et al, cited by Macek (1986), in the 1950s. Although the cited study employed methods that were representative of the time, and statistical evaluations were lacking, the team measured different variables of circulation in children, and stated that the level of blood flow is higher in children than in adults, probably because of the relatively larger diameter of large vessels in relation to the heart size. In 1978, Koch studied the local blood flow across the working muscle, after ischemic work and during cycle ergometer exercise and found that it was 30\% higher in children than in adults. Such age-related differences provide indirect support for the view that muscle blood flow in pre-pubertal children may be higher than that of older children and adults.

The oxygen uptake kinetics during a non-steady state maximal intensity exercise, such as that during a WAnT in young children has apparently not been described. The use of breath-by-breath analysis facilitates the monitoring of exercise peak $\mathrm{V}_{2}$ during maximal intensity exercise and provides valuable information about young people's ventilatory responses during this sort of non-steady state exercise.

\section{Conclusion}

Data to explain the relative inaptitude of young people to perform maximal intensity exercise in comparison to adults can be organised into two main schools of thought-one supporting the hypothesis that young people are indeed less physiologically equipped to perform high intensity exercise than adults, and the other, that young people are better equipped aerobically and are therefore less reliant on anaerobic energy pathways in responding to maximal intensity exercise. Either way, the current data are equivocal. Future research that uses and magnetic resonance spectroscopy technology when investigating young people's maximal intensity exercise performance may bring to the fore a better understanding of the issue.

\section{References}

Armon, Y., Cooper, D.M., Flores, R., Zanconato, S., \& Barstow, T.J. (1991). Oxygen uptake dynamics during high-intensity exercise in children and adults. Journal of Applied Physiology, 70, 841-848.

Armstrong, N., \& Welsman, J. (1997). Young People and Physical Activity. Oxford University Press.

Armstrong, N., \& Welsman, J.R. (1994). Assessment and interpretation of aerobic fitness in children and adolescents. Exercise and Sport Sciences Reviews, 22, 435-476.

Asai, H., \& Aoki, J. (1996). Force development of dynamic and static contractions in children and adults. International Journal of Sports Medicine, 17, 170-174.

Asmussen, E., \& Heeboll-Nielsen, K.A. (1955). A dimensional analysis of physical performance and growth in boys Journal of Applied Physiology, 7, 593.

Astrand, P-O., \& Rodah, K. (1986). Textbook of Work Physiology, (3rd ed.). McGraw Hill.

Backman, E., \& Henriksson, K.G. (1988). Skeletal muscle characteristics in children 9-15 years old: force, relaxation rate and contraction time. Clinical Physiology, 8, 521527.

Bale, P., Mayhew, J.L., Piper, F.C., Ball, T.E., \& William M.K. (1992). Biological and performance variables in relation to age in male and female adolescent athletes. Journal of Sports Medicine and Physical Fitness, 32, 142-148. 
Balwin, K.M. (1984). Muscle development: Neonatal to adult. Exercise and Sports Science Reviews, 12, 1-19.

Bar-Or, O. (1983), Pediatric Sports Medicine for the Practitioner. New York, Springer-Verlag.

Bar-Or, O. (1989). Children: lower anaerobic power, testing, puberty, and carryover to adulthood. In: Future Directions In Exercise and Sports Science Research. Skinner, J. S. (Ed.). Champaign IL, Human Kinetics. pp.48-53.

Barstow, T.J. (1994). Characterisation of oxygen uptake kinetics during heavy exercise. Medicine and Science in Sports and Exercise, 26, 1327-1334.

Bass, A., Gutmann, E., Hanzikova, V., \& Syrovy, I. (1971). Sexual differentiation of enzyme pattern and its conversion by testosterone in the temporal muscle of the guineapig. Physiologica Bohemeslovaca, 20, 423-431.

Belanger, A.Y., \& McComas, A.J. (1981). Extent of motor unit activation during effort. Journal of Applied Physiology, 51, 1131-1135.

Belcastro, A.N., \& Bonen, A. (1975). Lactic acid removal rates during controlled and uncontrolled recovery exercise. Journal of Applied Physiology, 39, 932-936.

Bell, R.D., MacDougall, J.D., Billeter, R., \& Howard, H. (1980). Muscle fibre types and morphometric analysis of skeletal muscle in 6-year-old children. Medicine and Science in Sports and Exercise, 12, 28-31.

Berg, K., Kim, S.S., \& Keul, J. (1986). Skeletal muscle enzyme activities in healthy young subjects. International Journal of Sports Medicine, 7, 236-239.

Bishop, P., \& Martino, M. (1993) Blood lactate measurement in recovery as an adjunct to training. Sports Medicine, $16,5-13$

Blimkie, C.J. (1989). Age- and sex- associated variation in strength during childhood: anthropometric, morphologic, neurologic, biomechanic, endocrinologic, genetic and physical activity correlates. In: Perspectives in Exercise Science and Sports Medicine Volume 2: Youth, Exercise and Sport, Gisolfi, C.V. \& Lamb, D.R. (Eds.), pp. 99157 Benchmark Press Inc., Indiana.
Blimkie, C.J., Roche, P., Hay, J.T., \& Bar-Or, O. (1989). Anaerobic power of arms in teenage boys and girls: relationship to lean tissue. European Journal of Applied Physiology, 57, 677-683.

Boulay, M.R., Song, T.M.K., Serresse, O., Theriault, G., Simoneau, J-A., \& Bouchard, C. (1995). Changes in plasma electrolytes and muscle substrates during short-term maximal exercise in humans. Canadian Journal of Applied Physiology, 20, 89-101

Brooke, M.H., \& Engel, W.K. (1969). The histographic analysis of human muscle biopsies with regard to fibre types:

4. Children's biopsies. Neurology, 19, 591-605.

Brooks, G.A., \& Fahey, T.D. (1984). Exercise Physiology. New York: John Wiley.

Brooks, G.A., \& Fahey, T.D. (1984). Exercise Physiology. New York: John Wiley.

Brooks, G.A. (1985). Anaerobic threshold: a review of concepts and directions for future research. Medicine and Science in Sports and Exercise, 17, 22-31.

Brooks, G.A. (1985). Anaerobic threshold: a review of concepts and directions for future research. Medicine and Science in Sports and Exercise, 17, 22-31.

Brooks, G.A. (1991). Current concepts in lactate exchange. Medicine and Science in Sports and Exercise, 23, 895906.

Chia, M., Armstrong, N., \& Childs, D. (1997). The assessment of children's Anaerobic performance using modifications of the Wingate Anaerobic Test. Pediatric Exercise Science, 9, 80-89.

Chia, Y.H.M. (2001). Power recovery in the Wingate Anaerobic Test in girls and women following prior sprints of a short duration. Biology of Sport, 18, 45-53.

Chia, Y.H.M., Lee, K.S., \& Teo-Koh, S.M. (2002). Reliability of the Wingate Anaerobic Test for adolescent boys with moderate intellectual disability. Biology of Sport, 19, 5163.

Coggan, A.R., \& Costill, D.L. (1984). Biological and technological variability of three anaerobic tests. International Journal of Sports Medicine, 5, 142-145. 
Colling-Saltin, A.S. (1980). Skeletal muscle development in the human foetus and during childhood. In: Children and Exercise IX, Berg, K. \& Eriksson, B.O. (Eds.). University Park Press. pp. 193-207.

Convertino, V.A., Keil, L.C., \& Greenleaf, J.E. (1991). Plasma volume, renin and vasopressin responses to graded exercise after training. Journal of Applied Physiology: Respiratory, Environmental and Exercise Physiology, 54, 508-514.

Costill, D.L., Fink, W.J., \& Pollock, M.L. (1976). Muscle fibre composition and enzyme activities of elite distance runners. Medicine and Science in Sport and Exercise, $8,96-100$.

Crielaard, J.M., \& Pirnay, F. (1981). Anaerobic and aerobic power of top athletes. European Journal of Applied Physiology and Occupational Physiology, 47, 295-300.

Cumming, G.R., Hastman, L., \& McCullough, S. (1980). High serum lactates do occur in children after maximal work. International Journal of Sports Medicine, 1, 66-69.

Davies, C.T.M. (1985). Strength and mechanical properties of muscle in children and young adults. Scandinavian Journal of Sports Science, 7, 11-15.

Davies, C.T.M., White, M.J., \& Young, K. (1983). Muscle function in children. European Journal of Applied Physiology, 52, 111-114.

de Knecht, S., \& Binkhost, R.A. (1980). Physical characteristics of children with congenital heart disease: Body characteristics and physical working capacity. In: Children and Exercise IX, International Sports Science Series, Berg, K. \& Eriksson, B.O. (Eds.). Baltimore: University Park Press. pp. 333346.

du Plessis, M.P., Smit, P.J., du Plessis, L.A.S., Geyer, G., Mathews, G., \& Louw, H.N.J. (1985). The composition of muscle fibres in a group of adolescents. In: Children and Exercise XI, Binkhorst, R.A., Kemper, H.C.G. \& Saris, W.H.M. (Eds.). Champaign IL, Human Kinetics. pp.323-328.

Dux, L., \& Guba, F. (1982). Further data on the androgenic dependency of the skeletal musculature: the effect of pre-pubertal castration on the structural development of the skeletal muscles. Hormone and Metabolic Research, 14, 191-194.
Elder, G.C.B., Bradbury, K., \& Roberts, R. (1982). Variability of fibre distributions within human muscles. Journal of Applied Physiology, 53, 1473-1480.

Ennion, S., Sant'Ana Pereira, J.A.A., Sargeant, A.J., Young, A., \& Goldspink, G. (1995). Characterisation of human skeletal muscle fibres according to myosin heavy chain they express. Journal of Muscle Research and Cell Motility, 16, 35-43.

Eriksson, B.O., \& Saltin, B. (1974). Muscle metabolism during exercise in boys aged 11 to 16 years compared to adults. Acta Pediatrica Belgica, 28, 257-265.

Eriksson, B.O. (1972). Physical training, oxygen supply and muscle metabolism in 11-13 year old boys. Acta Physiologica Scandinavica, 384, 1-48.

Eriksson, B.O. (1980). Muscle metabolism in children: a review. Acta Pediatrica Scandinavia, 283, 20-28.

Eriksson, B.O., Friberg, L-G., \& Mellgren, F. (1980). Muscle substrates, muscle enzyme activities, and muscle structure in infants with symptomatic ventricular septal defects, In: Children and Exercise IX, Berg, K. \& Eriksson, B.O. (Eds.). University Park Press. pp. 116-127.

Eriksson, B.O., Gollnick, P.D., \& Saltin, B. (1973). Muscle metabolism and enzyme activities after training in boys 11-13 years old. Acta Physiologica Scandinavica, 87, 485-497.

Falgairette, G., Bedu, M., Fellmann, N., Van Praagh, E., \& Coudert, J. (1991). Bioenergetic profile in 144 boys aged 6-15 years with special reference to sexual maturation. European Journal of Applied Physiology, 62, 151-156.

Falk, B. \& Bar-Or, O. (1993). Longitudinal changes in peak aerobic and anaerobic mechanical power in circumpubertal boys. Pediatric Exercise Science, 5, 318-331.

Fellmann, N., Bedu, M., Spielvogel, Falgairette, G. \& Van Praagh, E. (1988). Anaerobic metabolism during pubertal development at high altitude. Journal of Applied Physiology, 64, 1382-1386.

Fournier, M., Ricci, J., Taylor, A.W., Feruguson, R.J., Montpetit, R.R., \& Chairman, B.R. (1982). Skeletal muscle adaptation in adolescent boys: sprint and endurance training and detraining. Medicine and Science in Sports and Exercise, 14, 453-456. 
Freedson, P., Gilliam, S. Sady, P., \& Katch (1983). Transient V02 characteristics in children at the onset of steady rate exercise. Research Quarterly for Exercise and Sport, 52, 167-173.

Freund, H., \& Zoulouman, P. (1981). Lactate after exercise in man: evolution kinetics in arterial blood. European Journal of Applied Physiology and Occupational Physiology, $46,121-133$

Fujitsuka, N., Yamamoto, T., Ohkuwa, T., Saito, M., \& Muramura, M. (1982). Peak blood lactate after short periods of treadmill running. European Journal of Applied Physiology, 48, 289-296.

Galbo, H. (1983). Hormonal and metabolic adaptation to exercise. Stuttgart, George, Thieme.

Gaul, C.A., Docherty, D., \& Cicchinni, R. (1995). Differences in anaerobic performance between boys and men. International Journal of Sports Medicine, 16, 451-455.

Haralambie, G. (1979). Skeletal muscle enzyme activities in female subjects of various ages. Bulletin of European Physio-pathological Respiration, 15, 259-267.

Haschke, F. (1983) Body composition of adolescent males: total body water in adolescent males. Acta Pediatrica Scandinavica, 307, 1-12.

Hebestreit, H., Minura, K-I., \& Bar-Or, O. (1994). Recovery of muscle power after high intensity short-term exercise: comparing boys to men. Journal of Applied Physiology, 74, 2875-2880.

Hermansen, L. (1971). Lactate production during exercise. In: Muscle Metabolism During Exercise. Pernow, B. \& Saltin, B. (Eds.). New York, Plenum Press. pp. 25-31.

Hochachka, P.W. (1990). The biochemical limits of muscle work. In: Biochemistry of Exercise VII. Taylor et al (Eds.). Champaign IL, Human Kinetics. pp.33-42.

Houmard, J.A., Smith, R., \& Jendrasiak, G.I (1995). Relationship between MRI relaxation time and muscle fibre composition. Journal of Applied Physiology, 78, 807-809.
Inbar, O., \& Bar-Or, O. (1986). Anaerobic characteristics in male children and adolescents. Medicine and Science in Sports and Exercise, 18, 3.

Jacobs, I. (1986). Blood lactate: implications for training and sports performance. Sports Medicine, 3, 10-25.

Kelly, A., Lyons, B., Gambki, B., \& Rubinstein, N. (1985). Influences of testosterone on contractile proteins of the guinea pig temporalis muscle. Advances in Experimental and Biological Medicine, 182, 155-168.

Kindermann, V.W., Keul, J., \& Lehmann, M. (1975). Audauserbelastungen beim Heranwachsenden-metabolische und kardiozirkulatorische Verandergen. Fortschr. Med., 97, 659-665.

Koch, G. (1980). Adrenergic activity at rest and during exercise in normotensive boys and young adults, and in hypertensive patients. In: Children \& Exercise IX, Berg, K. \& Eriksson, B.O. (Eds.). Baltimore, University Park Press. pp.375381.

Komi, P.V. (1979). Neuro-muscular performance: factors influencing force and speed production. Scandinavian Journal of Sports Sciences, 1, 2-15.

Komi, P.V. (1984). Physiological and biomechanical correlates of muscle function: effects of muscle structure and stretchshortening cycle on force and speed. Exercise and Sports Science Reviews, 12, 81-121.

Kraemer, W.J. (1992) Hormonal mechanisms related to the expression of muscular strength and power. In: Strength and Power in Sport, Komi, P.V. (Ed.), London, Blackwell Scientific Publications. pp. 64-76.

Krotkiewski, M., Kral, J.G., \& Karlsson, J. (1980). Effects of castration and testosterone substitution on body composition and muscle metabolism in rats. Acta Physiologica Scandinvica, 109, 233-237.

Kuno, S., Katsuta, S., Inouye, T., Anno, I., Matsumoto, K., \& Akisada, M. (1988). Relationship between MR relaxation time and muscle fibre composition. Radiology, 169, 567568. 
Lehmann, M., Keul, J., \& Korten-Reck, U. (1981). The influence of graduated treadmill exercise on plasma catecholamines, aerobic and anaerobic capacity in boys and adults. European Journal of Applied Physiology, 47, 301-311.

Lexell, J., Sjostrom, M., Nordlund, A., \& Taylor, C.C. (1992). Growth and development of human muscle: a quantitative morphological study of whole vastus lateralis from childhood to adult age. Muscle Nerve, 15, 404-409.

Lexell, J., Taylor, C.C., \& Sjostrom, M. (1985). Analysis of sampling errors in biopsy techniques using data from whole muscle cross sections. Journal of Applied Physiology, 59, 1228-1235.

Lloyd, R.D., \& May, C.W. (1987). A model of human body composition by total body counting. Human Biology, 59, 7-30.

Lohman, T.G. (1985). Applicability of body composition techniques and constants for children and youth. Exercise and Sports Science Reviews, 14, 325-357.

Lowery, G.H. (1973). Growth and Development of Children. Chicago. Year Medical Book.

Lundberg, A., Eriksson, B.O., \& Mellgren, G. (1979). Metabolic substrates, muscle fibre composition, and fibre size in late walking and normal children. European Journal of Pediatrics, 130, 79-92.

Macek, M. \& Varva, J., \& Novosadeva, J. (1976). Prolonged exercise in pre-pubertal boys. European Journal of Applied Physiology, 35, 291-298.

Macek, M., \& Varva, J. (1980). The adjustment of oxygen uptake at the onset of exercise: comparison between prepubertal boys and young adults. International Journal of Sports Medicine, 1, 75-77.

Macek, M. (1986). Aerobic and anaerobic energy output in children. In: Children and Exercise XII, Rutenfranz, J. \& Mocellin, R. (Eds.). Champaign, IL, Human Kinetics. pp. 3-9.

Malina, R. (1969). Quantification of fat, muscle, and bone in man. Clinical Orthopaedics, 65, 9-38.

Malina, R.M., \& Bouchard, C. (1986). Sports and Human Genetics. Champaign, IL. Human Kinetics.
Matejkova, J., Koprivova, Z.,\& Placheta, Z. (1980). Changes in acid-base balance after maximal exercise. In: Youth and Physical Activity, Placeheta, Z. ( Ed. ). Brno: J. E. Purkyne University. pp.191-199.

Mazzeo, R.S., \& Marshall, P. (1989) Influence of plasma catecholamines on the lactate threshold during graded exercise. Journal of Applied Physiology, 67, 1319-1322.

Mercier, B., Mercier, J., Grainer, P., Le Gallais, D., \& Prefaut, C.H. (1992). Maximal anaerobic power; relationship to anthropometric characteristics during growth. International Journal of Sports Medicine, 13, 21-26.

Murphy, M.M., Patton, J.F., \& Frederick, F.A. (1984). A comparison of anaerobic power capacity in males and females accounting for differences in thigh volume, body weight, and lean body mass. Medicine and Science in Sports and Exercise, 16, 108.

Naughton, G.A., Carlson, J.S., Buttifant, S.R., Selig, S.E., \& Snow, R.S. (1993). Plasma lactate and ammonia responses following supra-maximal anaerobic capacity testing in trained adolescent and adult athletes. Pediatric Exercise Science, 5, 450 .

Naveri, H. (1985). Blood hormone and metabolite levels during graded cycle ergometer exercise. Scandinavian Journal of Clinical Laboratory Investigations, 45, 599-603.

Oertel, G. (1988). Morphometric analysis of normal skeletal muscles in infancy, childhood and adolescence. Journal of Neurological Science, 88, 303-313.

Paterson, D.H., Cunningham, D.A., \& Bumstead, L.A. (1986). Recovery $\mathrm{O} 2$ and blood lactic acid: longitudinal analysis in boys aged 11 to 15 years. European Journal of Applied Physiology, 55, 93-99.

Poole, D.C. (1994). Role of exercising muscle in slow component of oxygen uptake. Medicine and Science in Sports and Exercise, 26, 1335-1340.

Rieu, M., Duvallet, A., Scharapan, L., Thieulart, L., \& Ferry, A. (1988). Blood lactate accumulation in intermittent supramaximal exercise. European Journal of Applied Physiology, $57,235-245$.

Robinson, S. (1938). Experimental studies of physical fitness in relation to age. Arbeitsphysiologie, 10, 251-323. 
Rowland, T.W. (1990). Exercise and Children's Health. Champaign, IL, Human Kinetics.

Rowland, T.W., Maresch, C.M., Charkoudian, N., Vanderburgh, P.M., Castellani, J.W., \& Armstrong, L.E. (1995). Relationship between plasma lactate and epinephrine during exercise in boys. In: Exercise and Fitness: Benefits and Risks Symposium XVII. European Group of Pediatric Work Physiology Proceedings. pp. 48.

Rowland, T.W., Maresch, C.M., Charkoudian, N., Vanderburgh, P.M., Castellani, J.W., \& Armstrong, L.E. (1996). Plasma norepinephrine responses to cycle exercise in boys and men. International Journal of Sports Medicine, 17, 2226.

Sady, S.P., Katch, V.L., Villanacci, J.F., \& Gilliam, T.B. (1983). Child-adult comparisons of V02 and HR kinetics during sub-maximum exercise. Research Quarterly for Exercise and Sport, 54, 55-59.

Sale, D.G. (1989). Strength training in children. In: Perspectives in exercise science and sports medicine. Vol 2, Gisolfi, C.V. \& Lamb, D.R. (Eds.). Youth, Exercise and Sport. Indianapolis: Benchmark Press. pp.165-222.

Sant' Ana Pereira, J.A.A., Sargeant, A.J., Rademaker, A.C. H., de Haan, A., \& van Mechelen, W. (1996). Myosin heavy chain isoform expression and high energy phosphate content in human muscle fibres at rest and post-exercise. Journal of Physiology, 496, 583-588.

Sargeant, A.J. (1989). Short-term muscle power in children and adolescents, In: Advances in Pediatric Sports Sciences, Biological Issues, Bar-Or, O. (Ed.) Champaign, IL, Human Kinetics. pp. 41-65.

Sargeant, A.J. (1994). Human power output and muscle fatigue. International Journal of Sports Medicine, 15, 116-121.

Sargeant, A.J., Dolan, P., \& Young, A. (1984). Optimal velocity for maximal short-term (anaerobic) power output in cycling. International Journal of Sports Medicine, 5, 124-125.

Savard, G.K., Strange, S., Kiens, B., Saltin, B., Richter, E. A., \& Christensen, N.J. (1987). Norepinephrine spill-over during exercise in active versus resting skeletal muscle in man. Acta Physiologica Scandinavica, 131, 507-515.
Shephard, R.J., Allen, C., Bar-Or, O., \& Davies, C.T. (1969). The work capacity of Toronto school children Part 1. Canadian Medical Journal, 100, 560-566.

Simoneau, J.A., Lortie, G., Boulay, M.R., Thibault, M.C., Theriault, G., \& Bouchard, C. (1985). Skeletal muscle histochemical and biochemical characteristics in sedentary male and female subjects. Canadian Journal of Physiology and Pharmacology, 63, 30-35.

Slaughter, M.H., Lohman, T.G., \& Boileau, R.A. (1988) Skinfold equations for estimation of body fatness in children and youth. Human Biology, 60, 709-723.

Soucer, C., Lapa, A.J., \& do-Valle, R.J. (1982). The influence of testosterone on neuro-muscular transmission in hormone sensitive mammalian skeletal muscles. Muscle and Nerve, 5, 232-237.

Spriet, L.L., Ren, J.M., \& Hultman, E. (1988) Epinephrine infusion enhances muscle glycogenolysis during prolonged electrical stimulation. Journal of Applied Physiology, 64, 1439-1444.

Stainsby, W.N. (1986). Biochemical and physiological basis for lactate production. Medicine and Science in Sports and Exercise, 18, 341-343.

Stanley, W.C., \& Brooks, G.A. (1986) Measuring lactate production (letter to the editor). American Journal of Physiology, 253, E472-E473.

Stegmann, H., Kindermann, W., \& Schnabel (1981). Lactate kinetics and individual anaerobic threshold. International Journal of Sports Medicine, 2, 160-165.

Suurnakki, T., Illmarinen, J., Nygard, G.H., Komi, P.V., \& Karlsson, J. (1986). Anaerobic strain in children during a cross-country skiing competition, In: Children and Exercise XII, Rutenfranz et al (Eds.). Champaign, Illinois, Human Kinetics. pp. 67-75.

Thomas, J.R., \& Nelson, J.K. (1990). Research methods in physical activity. Champaign, IL: Human Kinetics.

Vandewalle, H., Peres, G., \& Monad, H. (1987). Standard Anaerobic Exercise Tests. Sports Medicine, 4, 268-289. 
Von Ditter, H., Nowacki, P., Simai, E., \& Winkler, U. (1977). Das Verhaltan des Saure-basen-haushalts nach erschopfender Belastung bei untrainierten und trainerten Jungen und Vergleich zu Leistungssportlern. Sportarzt Sport Medicine, $28,45-48$.

Vrijens, J. (1978). Muscle strength development in the preand post- pubescent age. Medicine and Sport, 11, 152158.

Wells, C. L. (1989). Women, sport and performance: A physiological perspective. Champaign, IL: Human Kinetics.

Welsman, J.R., \& Armstrong, N. (1995). The interpretation of peak volume oxygen in pre-pubertal children. In: Children in Sport, Ring, F.J. (Ed.), Bath, Centre for Continuing Education. pp.64-69.

Whipp, B. (1994). The slow component of oxygen uptake kinetics during heavy exercise. Medicine and Science in Sports and Exercise, 26, 1319-1326.

Whittlesey, M.J., Maresh, C.M., Armstrong, L.E., Morocco, T.S., Hannon, D.R., Gabaree, L.V., \& Hoffman, J.R. (1996). Plasma volume responses to consecutive anaerobic exercise tests. International Journal of Sports Medicine, $17,268-271$.

Williams, C.A. (1995). Anaerobic performance of prepubescent and adolescent children. Ph.D. Thesis. University of Exeter, UK.

Williams, C.A., Armstrong, N., Fox, K.R., Kirby, B.J., Peters, D.M., Welsman, J.R., Sharpe, P., \& Bell, M. (1993). Aerobic and anaerobic performance in 11-year-old children in relation to thigh composition: a preliminary study using magnetic resonance imaging. Pediatric Exercise Science, 5, 486 .

Williams, J.R., Armstrong, N., \& Kirby, B.J. (1992). The influence of the site of sampling and assay medium upon the measurement and interpretation of blood lactate responses to exercise. Journal of Sports Sciences, 10, 95-107.

Wilmore, J. H., \& Costill, D.L. (1994). Physiology of Sport and Exercise. Champaign, IL: Human Kinetics.
Winter, J.S.D. (1978). Pre-pubertal and pubertal endocrinology. In: Human Growth, Falkner, F. \& Tanner, J.M. (Eds.). New York, Plenum Press. pp. 183-213.

Zanconato, S., Buchthal, S., Barrow, T.J., \& Copper, D.M. (1993). 31 P-magnetic resonance spectroscopy of leg muscle metabolism during exercise in children and adults. Journal of Applied Physiology, 74, 2214-2218.

Zanconato, S., Copper, D.M., \& Armon, Y. (1991). Oxygen cost and oxygen uptake dynamics and recovery with one minute of exercise in children and adults. Journal of Applied Physiology, 71, 993-998.

Zwiren, L.D. (1989). Anaerobic and aerobic capacities of children. Pediatric Exercise Science, 1, 31-44.

\section{Correspondence:}

\author{
Dr Michael Chia \\ Physical Education and Sports Science \\ National Institute of Education \\ Nanyang Technological University \\ 1 Nanyang Walk \\ Singapore 637616 \\ SINGAPORE \\ Tel: 65-67903701 \\ Fax: 65-68969260 \\ Email:yhmchia@nie.edu.sg
}

